Jurnal Health Sains: p-ISSN: 2723-4339 e-ISSN: 2548-1398

Vol. 2, No. 6, Juni 2021

\title{
PENGARUH PROGRAM SELF DIABETES MANAGEMENT EDUCATION (SDME) DENGAN METODA KELOMPOK TERHADAP DUKUNGAN KELUARGA DAN KUALITAS HIDUP PASIEN DIABETES MELLITUS
}

\author{
Ani Nuraeni \\ Politeknik Kesehatan Kemenkes Jakarta I, Indonesia \\ Email: aninuraeni49@yahoo.co.id
}

\begin{tabular}{l} 
ARTIKEL INFO \\
\hline Diterima: 5 Juni 2021 \\
Direvisi: 15 Juni 2021 \\
Disetujui: 25 Juni 2021 \\
\hline
\end{tabular}

\begin{abstract}
Diabetes mellitus can become serious and cause chronic conditions that are dangerous if left untreated. According to the World Health Organization (WHO) in 2011, diabetics are at risk of microvascular damage such as retinopathy, nephropathy, and neuropathy. This has an effect on the quality of life of DM sufferers.. The quality of life of DM patients can be improved in many ways. One of the methods that has been used to improve the quality of life of DMsufferers is the Self Diabetes Management Education (SDME) method with group methods. Self Diabetes Management Education (SDME) is an ongoing process to facilitate the knowledge, skills and abilities necessary for the self-care of Diabetes Mellitus patients. SDME provides decision making information, self-care behavior, problem solving and active cooperation with health teams and to improve clinical outcomes, health status and quality of life.. This study aims to find out the influence of Self Diabetes Management Education (SDME) with group methods on family support and quality of life of DM sufferers in the working area of Puskesmas Ragunan Village, South Jakarta. This study used Quasi Experiment design with DM patients in Ragunan Village Health Center Pasar Minggu as a sample.
\end{abstract}

Keywords:

diabetes mellitus; self diabetes

management education

\begin{abstract}
ABSTRAK
Diabetes mellitus dapat menjadi serius dan menyebabkan kondisi kronik yang membahayakan apabila tidak diobati. Menurut World Health Organization (WHO) tahun 2011, penderita diabetes berisiko mengalami kerusakan mikrovaskuler seperti retinopati, nefropati, dan neuropati.Hal tersebut memberikan efek terhadap kualitas hiduppenderita DM. Kualitas hidup pasien DM dapat ditingkatkan dengan banyak cara. Salah satu metode yang sudah digunakan untuk meningkatkan kualitas hidup penderita DM adalah Metode Self Diabetes Management Education (SDME) dengan metode kelompok. Self Diabetes Management Education (SDME) merupakan suatu proses berkelanjutan untuk memfasilitasi pengetahuan, ketrampilan dan kemampuan yang diperlukan untuk perawatan diri pasien

Diabetes Mellitus. SDME memberikan dukungan informasi
\end{abstract}

\begin{tabular}{ll}
\hline How to cite: & Nuraeni, Ani (2021) Pengaruh Program Self Diabetes Management Education (SDME) dengan \\
& Metoda Kelompok terhadap Dukungan Keluarga dan Kualitas Hidup Pasien Diabetes Mellitus.Jurnal \\
& Health Sains 2(6). https://doi.org/10.46799/jhs.v2i6.187 \\
E-ISSN: & 2723-6927 \\
Published by: & Ridwan Institute
\end{tabular}


Pengaruh Program Self Diabetes Management Education (SDME) dengan Metoda Kelompok terhadap Dukungan Keluarga dan Kualitas Hidup Pasien Diabetes Mellitus

Kata Kunci:

diabetes mellitus; self diabetes

management education

(SDME); kualitas hidup pengambilan keputusan, perilaku perawatan diri, pemecahan masalah dan kerjasama aktif dengan tim kesehatan dan untuk meningkatkan hasil klinis, status kesehatan dan kualitas hidup. Penelitian ini bertujuan untuk mengetahui pengaruh Self Diabetes Management Education (SDME) dengan Metode kelompok terhadap dukungan keluarga dan kualitas hidup penderita DM di wilayah kerja Puskesmas Kelurahan Ragunan Jakarta Selatan. Penelitian ini menggunakan desain Quasi Experiment dengan pasien DM di Puskesmas Kelurahan Ragunan Pasar Minggu sebagai sampel.

\section{Pendahuluan}

Penyakit tidak menular (PTM) merupakan salah satu masalah kesehatan yang banyak di derita masyarakat Indonesia saatini. Penyakit tidak menular cenderung terus meningkat secara global dan nasional telah menduduki sepuluh besar penyakit penyebab kematian. Kasus terbanyak dari penyakit tidak menular tersebut salah satunya adalah diabetes mellitus (DM) (DepKes, 2008).

Diabetes Atlas edisi ke- 8 yang diterbitkan oleh Federasi Diabetes Internasional 2017 menyatakan bahwa 425 juta dari total populasi seluruh dunia, atau sekitar 8,8 persen orang dewasa berumur 2079 tahun merupakan penderita diabetes.

Data tersebut juga mengungkapkan bahwa menempati peringkat ke-6 sebagai jumlah penderita diabetes dewasa tertinggi di dunia dengan total lebih dari 10,3 juta orang. Angka ini diprediksi akan terus mengalami peningkatan dan mencapai 16, 7 juta pada tahun 2045.

Di Indonesia sendiri, berdasarkan data terbaru Riset Kesehatan Dasar 2018, secara umum angka prevalensi diabetes mengalami peningkatan cukup signifikan selama lima tahun terakhir. Di tahun 2013, angkaprevalensi diabetes pada orang dewasa mencapai 6,9 persen, dan di tahun 2018 angkaterus melonjak menjadi 8,5 persen.

Diabetes mellitus dapat menjadi serius dan menyebabkan kondisi kronik yang membahayakan apabila tidak diobati. Menurut World Health Organization (WHO) tahun 2011, penderita diabetes berisiko mengalami kerusakan mikrovaskuler seperti retinopati, nefropati, dan neuropati. Hal tersebut memberikan efek terhadap kualitas hidup penderita DM (Herdianti et al., 2020).

Diabetes mellitus merupakan penyakit kronis yang tidak bisa disembuhkan tetapi bisa dikendalikan, yaitu sekali terdiagnosa DM seumur hidup, penderita DM mampu hidup sehat bersama DM, asalkan mau patuh dan kontrol teratur. Prevalensi diabetes mellitus tergantung insulin di Provinsi Jawa Tengah pada tahun 2012 sebesar $0,06 \%$, pravelensi tertinggi adalah Kabupaten Semarang sebesar 0,66\% (Dinkes, 2013).

Diabetes mellitus digambarkan sebagai penyakit yang gejalanya adalah sering kencing sehingga disebut pula dengan penyakit kencing manis. Pada pasien yang menderita penyakit diabetes mellitus kadar gulanya menjadi meningkat. Pada saat itu tubuh tidak bisa menggunakan glukosa yang ada didalam darah untuk diubah menjadi energi karena penumpukan atau kelebihan glukosa dalam darah (Erik, 2005).

Tujuan pengobatan DM antara lain mengurangi risiko komplikasi penyakit mikrovaskuler dan makrovaskuler, memperbaiki gejala komplikasi, dan mengurangi jumlah kasus kematian, serta meningkatkan kualitas hidup penderita DM. Upaya pencegahan komplikasi DM yang kurang tepat dapat berpotensi mempengaruhi kualitas hidup penderita DM (Antari et al., 2011). 
Dukungan keluarga adalah sikap, tindakan dan penerimaan keluarga terhadap anggotanya. Anggota keluarga dipandang sebagai bagian yang tidak terpisahkan dalam lingkungan keluarga. Anggota keluarga memandang bahwa orang yang bersifat mendukung selalu siap memberikan pertolongan dan bantuan jika diperlukan.

Kualitas hidup adalah persepsi individu terhadap posisi mereka dalam kehidupan dan konteks budaya serta sistem nilai dimana mereka hidup dan dalam hubungannyadengan tujuan individu, harapan, standar, dan perhatian (Organization, 2002). Dalam kualitas hidup terdapat delapan domain kualitas hidup pasien DM tipe 2 yaitu keterbatasan peran karena kesehatan fisik, kemampuan fisik, kesehatan umum, kepuasan pengobatan, frekuensi gejala, masalah keuangan, kesehatan psikologis, dankepuasan diet (Yuli \& Harris, 2017).

Kualitas hidup menurut World Health Organozation Quality of Life (WHOQOL) Group (Rapley, 2003), didefinisikan sebagai persepsi individu mengenai posisi individu dalam hidup dalam konteks budaya dansistem nilai dimana individu hidup dan hubungannya dengan tujuan, harapan, standar yang ditetapkan dan perhatian seseorang. (Nimas, 2012).

Kualitas hidup pasien DM dapat ditingkatkan dengan banyak cara. Salah satu metode yang sudah digunakan untuk meningkatkan kualitas hidup penderita DM adalah Metode Self Diabetes Management Education (SDME) dengan metode kelompok.

Self Diabetes Management Education (SDME) merupakan suatu proses berkelanjutan untuk memfasilitasi pengetahuan, ketrampilan dan kemampuan yang diperlukan untuk perawatan diri pasien Diabetes Mellitus. SDME memberikan dukungan informasi pengambilan keputusan, perilaku perawatan diri, pemecahan masalah dan kerjasama aktif dengan tim kesehatan dan untuk meningkatkan hasil klinis, status kesehatan dan kualitas hidup (Cheng et al., 2009).

Self Diabetes Management Education adalah elemen penting dari perawatan untuk semua penderita diabetes dan mereka yang berisiko untuk mengembangkan penyakit. Hal ini diperlukan untuk mencegah atau menunda komplikasi diabetes dan memiliki unsur terkait untuk perubahan gaya hidup yang jugapenting untuk individu dengan prediabetes sebagai bagian dari upaya untuk mencegah penyakit (Haas et al., 2012).

Metode kelompok pada penderita DM terbukti mampu meningkatkan kualitas hidup penderita DM (Asmat et al., 2016). Hal ini terlihat dari penderita yang aktif dalam kegiatan kelompok DM dibandingkan dengan anggota yang tidak aktif.

Penelitian ini bertujuan untuk mengetahui pengaruh Self Diabetes Management Education (SDME) dengan Metode kelompok terhadap kualitas hidup penderita DM di wilayah kerja Puskesmas Kelurahan Ragunan Pasar Minggu Jakarta Selatan.

Manfaat penelitian Memberikan motivasi bagi pihak pelayanan kesehatanuntuk mempertimbangan terus menggunakan/ mempertahankan program Self Diabetes Management Education (SDME) di masyarakat.

\section{Metode Penelitian}

Desain penelitian dalam penelitian ini menggunakan desain kuasi eksperimen, dengan tujuan melihat pengaruh SDME (Self Diabetic Management Education) dengan metode kelompok dalam meningkatkan kualitas hidup penderita DM (Diabetes Mellitus) di kelurahan Ragunan Pasar Minggu Jakarta Selatan.

Pemberian SDME untuk kelompok intervensi dan kelompok Kontrol. Kelompok intervensi dan kelompok kontrol sama- sama berlokasi di wilayah kerja puskesmas 
Pengaruh Program Self Diabetes Management Education (SDME) dengan Metoda Kelompok terhadap Dukungan Keluarga dan Kualitas Hidup Pasien Diabetes Mellitus

kelurahan Ragunan. Pemberian SDME (Self Diabetic Management Education) dengan metode kelompok kecil pada penderita DM dilakukan untuk kelompok intervensi. Kelompok kontrol dilakukan SDME secara kelompok besar

Didalam Penelitian ini peneliti juga menggunakan pre test dan post test designwith control group, yaitu suatu pengukuran hanya dilakukan pada sebelum dan saat akhir intervensi. Pre test dilakukan pada kelompok intervensi dan kelompok kontrol untuk mengetahui data dasar yang akan digunakan untuk mengetahui efek dari variabel independen. Post test dilakukan pada kelompok intervensi dan kelompok kontrol setelah dilakukan perlakuan pelatihan. Hasil pengukuran dari ke dua kelompok tersebut dibandingkan.

Rentang waktu pemberian pretest dan post test adalah 30 hari. Hal ini sesuai dengan teori evaluasi bahwa jarak antara dua pengukuran minimum 2 (dua) minggu untuk pengetahuan dan minimum1 bulan untuk perilaku (Budiharto et al., 2008).

Populasi dalam penelitian ini adalah penderita DM yang belum pernah dilakukan SDME sebagai kontrol di Puskesmas kelurahan Ragunan dan Penderita DM yang belum pernah mendapat pelatihan SDME sebagai intervensi di Puskesmas Kelurahan Ragunan Pasar Minggu Jakarta Selatan pada masa periode bulan Juli s/d bulan Oktober 2018.

Sampel adalah objek yang diteliti dan dianggap mewakili seluruh populasi (Notoatmodjo, 2010). Teknik pengambilan sampel menggunakan teknik purposive sampling dimana pengambilan sampel didasarkan pada pertimbangan tertentu yang dibuat oleh peneliti sendiri yaitu sesuai dengan kriteria inklusi.

\section{Hasil dan Pembahasan}

\section{A. Hasil Penelitian}

1. Karakteristik Responden

Penelitian ini bertujuan untuk mengidentifikasi pengaruh programSelf

Diabetes Management Education (SDME) dengan metoda kelompok terhadap dukungan keluarga dan kualitas hidup pasien diabetes mellitus di wilayah kerja puskesmas kelurahan ragunan kecamatan Pasar Minggu.yang telah dilaksanakan pada bulan Agustus sd November 2019. Jumlah subjek dalam penelitian ini sebanyak 60 responden terdiri dari 30 responden kelompok intervensi dan 30 responden kelompok kontrol. Responden dipilih berdasarkan kriteria inklusi yang sudah ditetapkan, data diambil sebelum dan setelah dilakukan intervensi. Pengambilan data dilakukan di posbindu yang berada di wilayah kerja Puskesmas Kelurahan Rragunan Kecamatan Pasar Minggu Jakarta Selatan. Hasil penelitian ini diuraikan berdasarkan tujuan penelitian dan berdasarkan urutan analisis, yaitu hasil analisis univariat, analisis bivariat, dan analisis multivariat.

\section{Tabel 1}

Distribusi Responden menurut Umur, Pendidikan, Jenis Kelamin, dan Lamanya Menderita Diebetes

Melitus

\begin{tabular}{llcc}
\hline \multicolumn{2}{c}{ Karakteristik Responden } & N & \% \\
\hline Umur & 18-65 tahun & 43 & 71.7 \\
\hline & 66-79 tahun & 16 & 26.7 \\
\hline Pendidikan & 80-99 tahun & 1 & 1.7 \\
\hline & SD & 15 & 25.0 \\
\hline & SMP & 28 & 46.7 \\
\hline & SMA & 9 & 15.0 \\
\hline Lama DM & PT & 8 & 13.3 \\
\hline & $\leq 5$ tahun & 39 & 65.0 \\
\hline Jenis Kelamin & Laki-laki & 21 & 35.0 \\
\hline & Perempuan & 15 & 25.0 \\
\hline Total & & 60 & 75.0 \\
\hline
\end{tabular}

Karakteristik responden (total) berdasarkan umur responden, 
didapatkan ada sebanyak $71,7 \%$ untuk responden dengan umur 16-65 tahun, $26,7 \%$ berumur $66-79$ tahun, dan $1,7 \%$ responden dengan umur 80-99 tahun. Responden dengan pendidikan SD sebanyak $25 \%$, SMP $46,7 \%$, SMA $15 \%$ dan sisanya Perguruan Tinggi sebanyak $13,3 \%$. Dilihat dari lamanya responden menderita Diabetes Melitus, didapatkan angkA sebesar $65 \%$ responden dengan lama $\mathrm{DM} \leq 5$ tahun dan sisanya sebanyak $35 \%$ responden dengan lama $\mathrm{DM}>5$ tahun. Jika dilihat berdasarkan jenis kelamin, Perempuan didapati angka terbesar yakni $75 \%$, sisanya lakilaki sebesar $25 \%$.

Tabel 2

Uji Kenormalan

\begin{tabular}{|c|c|c|c|c|c|c|}
\hline \multirow{2}{*}{$\begin{array}{l}\text { Kualitas } \\
\text { Hidup } \\
\text { Pasien DM }\end{array}$} & \multirow{2}{*}{ N Mean } & \multirow{2}{*}{ SD } & \multirow{2}{*}{ Min } & \multirow[t]{2}{*}{$\operatorname{Max}$} & \multicolumn{2}{|c|}{$\begin{array}{c}\text { Kolmogorov } \\
\text { Smirnov }\end{array}$} \\
\hline & & & & & $\begin{array}{c}\text { Test } \\
\text { Statistik }\end{array}$ & $\begin{array}{c}P \text { - } \\
\text { value }\end{array}$ \\
\hline $\begin{array}{l}\text { Gula } \\
\text { Darah }\end{array}$ & 60193.08 & 85.72 & 44 & 471 & 0,119 & $\mathbf{0 , 0 3 4}$ \\
\hline $\begin{array}{l}\text { Tekanan } \\
\text { Darah } \\
\text { Sistole }\end{array}$ & 60137.08 & 17.90 & 110 & 190 & 0,187 & $\overline{0,000}$ \\
\hline $\begin{array}{l}\text { Tekanan } \\
\text { Darah } \\
\text { Diastole }\end{array}$ & 6075.83 & 8.48 & 52 & 114 & 0,228 & $\overline{0,000}$ \\
\hline
\end{tabular}

Berdasarkan kualitas hidup responden DM dapat dilihat bahwa hasil ukur Gula Darah Sewaktu (GDS) terendah adalah 44 dan tertinggi 471 dengan rata-rata193,08. Jika melihat angka Tekanan Darah Sistole (TDS), dapat dilihat angka terendah adalah sebesar 110 dan tertinggi 190 dengan nilai rata-rata sebesar 137,08. Selanjutnya perolehan angka Tekanan Darah Diastole (TDD) nilai terendah didapatkan angka 52 dan tertinggi di angka 114 dengan rata-rata 75,83.

Hasil uji kenormalan data (uji Kolmogorov-Smirnov) menunjukkan bahwa data hasil pengukuran GDS berdistribusi normal ( $\mathrm{p}$-value $>0,05$ ). Untuk hasil pengukuran TDD dan TDS didapatkan hasil tidak berdistribusi normal (p-value $<0,005$ ).

2. Analisis Bivariat

Perbedaan kualitas hidup pasien DM sebelum dan sesudah implementasi program Self Diabetes Management Education (SDME) dengan metoda kelompok di wilayah kerja Puskesmas kelurahan Ragunan Pasar Minggu Jakarta Selatan.

Tabel 3

Perbedaan kualitas hidup pasien DM sebelum dan sesudah implementasi program Self Diabetes Management Education (SDME) dengan metoda

\section{kelompok}

\begin{tabular}{lcccccc}
\hline $\begin{array}{l}\text { Kualitas Hidup } \\
\text { Pasien DM }\end{array}$ & N & Mean & SD & Min & Max & $\begin{array}{c}\text { P- } \\
\text { value }\end{array}$ \\
\hline $\begin{array}{l}\text { Gula Darah } \\
\text { (Pretest) }\end{array}$ & 30 & 194.83 & 76.47 & 100 & 431 & $\mathbf{0 , 0 2 2}$ \\
\hline $\begin{array}{l}\text { Gula Darah } \\
\text { (Posttest) }\end{array}$ & 30 & 158.60 & 62.90 & 77.00 & 371.00 & \\
\hline $\begin{array}{l}\text { Tekanan Darah } \\
\text { Sistole (Pretest) }\end{array}$ & 30 & 134.27 & 10.21 & 115 & 158 & 0,128 \\
\hline $\begin{array}{l}\text { Tekanan Darah } \\
\text { Sistole } \\
\text { (Posttest) }\end{array}$ & 30 & 128.83 & 15.37 & 80.00 & 173.00 & \\
\hline $\begin{array}{l}\text { Tekanan Darah } \\
\text { Diastole } \\
\text { (Pretest) }\end{array}$ & 30 & 73.47 & 7.43 & 52 & 90 & 0,468 \\
\hline $\begin{array}{l}\text { Tekanan Darah } \\
\text { Diastole } \\
\text { (Posttest) }\end{array}$ & 30 & 76.57 & 23.79 & 50.00 & 196.00 & \\
\hline
\end{tabular}

Berdasarkan tabel di atas didapatkan bahwa rata-rata Gula Darah responden sebelum intervensi adalah 194,83 dengan standar deviasi 76,47, setelah intervensi menjadi 158,60 dengan standar deviasi 62,90. Hasil uji statistik didapatkan nilai p-value 0,002 $(<0,005)$ yang artinya terdapat perbedaan rata-rata gula darah sebelum dan sesudah pemberian intervensi.

3. Analisis Multivariat

Pengaruh karakteristik (usia, jenis kelamin, pendidikan dan lama DM) terhadap kualitas hidup (TDS) pasien DM yang dilakukan Self Diabetes Management Education (SDME) dengan metode kelompok di Jurnal Health Sains, Vol 2, No 6, Juni 2021 
Pengaruh Program Self Diabetes Management Education (SDME) dengan Metoda Kelompok terhadap Dukungan Keluarga dan Kualitas Hidup Pasien Diabetes Mellitus

wilayah kerja Puskesmas kelurahan

Ragunan Pasar Minggu Jakarta Selatan.

Tabel 4

Pengaruh karakteristik (usia, jenis

kelamin, pendidikan dan lama DM) terhadap kualitas hidup (TDS) pasien DM yang dilakukan Self

Diabetes Management Education (SDME) dengan metode kelompok

\begin{tabular}{|c|c|c|c|c|}
\hline \multirow{2}{*}{$\begin{array}{l}\text { Tekanan } \\
\text { Darah } \\
\text { Sistolik } \\
\end{array}$} & Coef. & \multicolumn{2}{|c|}{$95 \% \mathrm{CI}$} & \multirow[t]{2}{*}{$\underline{P>t}$} \\
\hline & \multicolumn{2}{|r|}{ Lower } & Upper & \\
\hline SDME & -1.99 & -4.16 & 0.18 & 0.072 \\
\hline $\begin{array}{l}\text { Jenis } \\
\text { kelamin }\end{array}$ & & & & \\
\hline laki-laki & $\underline{\text { Reff }}$ & & & \\
\hline Perempuan & -3.40 & -17.01 & 10.22 & 0.619 \\
\hline \multicolumn{5}{|l|}{ Pendidikan } \\
\hline SD & Reff & & & \\
\hline SMP & 3.51 & -10.14 & 17.15 & 0.608 \\
\hline SMA & 1.97 & -15.80 & 19.75 & 0.825 \\
\hline PT & -2.31 & -20.56 & 15.94 & 0.8 \\
\hline \multicolumn{5}{|l|}{ Lama DM } \\
\hline$\leq 5$ tahun & $\underline{\text { Reff }}$ & & & \\
\hline$>5$ tahun & 7.31 & -3.93 & 18.56 & 0.198 \\
\hline \multicolumn{5}{|l|}{ Umur } \\
\hline $18-65$ th & $\underline{\text { Reff }}$ & & & \\
\hline $66-79$ th & -0.10 & -12.90 & 12.70 & 0.987 \\
\hline $80-99$ th & -4.21 & -47.99 & 39.56 & 0.848 \\
\hline
\end{tabular}

\section{B. Pembahasan}

Berdasarkan hasil penelitian yang diuraikan pada bagian A, selanjutnya akan diuraikan pembahasan hasil penelitian sebagai berikut:

1. Karakteristik responden

Hasil penelitian didapatkan gambaran bahwa sebagian besar responden berada pada usia 16 -65 tahun yaitu sebanyak 43 responden $(71,7 \%)$, Responden sebagian besar pendidikan SMP ( 46,7\%). Dilihat dari lamanya responden menderita Diabetes Melitus sebagian besar( $65 \%$ ) yaitu sebanyak 65 responden dengan lama $\leq$

5 tahun. Berdasarkan jenis kelamin sebagian besar perempuan sebanyak 45 responden $(75 \%$,

Hasil penelitian ini sesuaidengan (Ignatavicius,

mengatakan semakin meningkat usia maka prevalensi diabetes dan gangguan toleransi glukosa semakin meningkat.
Usia sangat erat kaitannya dengan DM tipe 2 dimana pada usia lanjut terjadi kenaikan kadar gula darah akibat resistensi insulin yang disebabkan karena menurunnya aktifitas, perubahan pola makan dan penurunan fungsi neurohormonal.

Demikian juga dengan pendapat (Ligaray \& Isley, 2009) yang menjelaskan bahwa DM tipe 2 lebih banyak dialami oleh dewasa. Penelitian lain dilakukan oleh (Sousa et al., 2009) yang menjelaskan bahwa DM ipe 2 lebih banyak terjadi pada perempuan dari pada laki-laki dan menurut Fitria responden perempuan lebih banyak $(54,4 \%)$ daripada laki-laki.

Hasil uji kesetaraan dengan uji homogenity test pada tabel 5.3 menunjukkan bahwa ada kesetaraan (homogenitas) antara data umur, pendidikan, lama DM, dan jeniskelamin pada kelompok kontrol dan kelompok intervensi (nilai p-value

$>0,05$ ). Hal ini menunjukan bahwa karakteristik responden antar kelompok intervensi dan kontrol tidak jauh berbeda. Begitu pula dengan hasil test gula darah dan tekanan darah diastole. Hal ini sesuai dengan teori bahwa hendaknya antara kelompok intervensi dan kelompok kontrol mempunyai kesamaan karakteristik. Hanya tekanan darah sistole yang tidak memiliki kesetaraan. Secara teoritis menyatakan bahwa pendidikan formal tinggi akan mempunyai pengetahuan yang lebih tinggi dibandingkan seseorang berpendidikan rendah (Notoatmodjo, 2010).

Gambaran dukungan keluarga sebelum dan sesudah diberikan intervensi SDME terdapat penurunan nilai minimum dari 48 menjadi 45 dengan nilai maksimal yang tetap sebesar 78. Hal ini dapat terjadi karena 
pada waktu pengisian kuisioner responden yang sebagian besar lansia mengalami kesulitan pada waktu membaca sehingga perlu mendapat bantuan dalam mengisi dan yang diisi kemungkinan tidak sesuia dengan kenyataan.

Gambaran kualitas hidup pada pasien sebelum intervensi dan sesudah intervensi berdasarkan hasil pemeriksaan gula darah didapat hasil penurunan kadar gula darah setelah dilakukan intervensi pemberian pendidikan kesehatan tentang DM menjadi rata- rata 158,6 dari 194,8.

2. Analisis Bivariat

Hasil analisis bivariat menunjukan terdapat perbedaan yang bermakna pada rata- rata gula darah pada responden yang dilakukan intervensi pada sebelum dan sesudah intervensi. Sebelum intervensi nilai rata- rata gula darah sebesar 194,83 turun menjadi rata- rata 158,60. Pada

Dukungan keluarga tidak terdapat perbedaan yang bermakna sebelum dan sesudah dilakukan intervensi pada kelompok intervensi.

Kualitas hidup antara kelompok intervensi dan kelompok kontrol tidak menunjukan perbedaan yang berarti pada saat sebelum dilakukan tindakan intervensi atau implementasi. Begitu pula untuk dukungan keluarga antara kelompok intervensi dan kelompok kontrol tidak menunjukan perbedaan yang bermakna.

3. Analisis Multivariat

Dukungan keluarga pasien DM meningkat setelah dilakukan intervensi setelha dikontrol oleh variabel karakteristik (Usia, Jenis kelamin, pendidikan dan pekerjaan). Hasil uji statistik didapatkan bahwa karakteristik (usia, jenis kelamin, pendidikan, lama DM) tidak berpengaruh terhadap kualitas hidup (GDS) pasien DM. Karakteristik (usia, jenis kelamin, pendidikan, lama DM) juga tidak berpengaruh terhadap dukungan keluarga pasien DM.

\section{Kesimpulan}

Laporan penelitian ini menunjukan hasil yang berbeda dengan hipotesa. Untuk pengetahuan ada perbedaan pada kelompok intervensi setelah dilakukan SDME dengan metoda kelompok dibandingkan dengan sebelum intervensi.

Ada perbedaan dalam kualitas hidup setelah dilakukan intervesi dengan meningkatnya kualitas hidup pasien DM yang dilakukan intervensi dibandingkan dengan kelompok kontrol. Hal ini terlihat dari penurunan rata- rata nilai gula darah sewaktu responden kelompok intervensi.

Hasil analisa pengaruh SDME terhadap kualitas hidup dan dukungan keluarga ternyata tidak ada pengaruhnya setelah dikontrol dengan karakteristik responden yaitu usia, jenis kelamin, pendidikan dan lama DM).

\section{BIBLIOGRAFI}

Antari, J., Chabaa, S., Iqdour, R., Zeroual, A., \& Safi, S. (2011). Identification Of Quadratic Systems Using Higher Order Cumulants And Neural Networks: Application To Model The Delay Of Video-Packets Transmission. Applied Soft Computing, 11(1), 1-10. Google Scholar

Asmat, U., Abad, K., \& Ismail, K. (2016). Diabetes Mellitus And Oxidative Stress-A Concise Review. Saudi Pharmaceutical Journal, 24(5), 547553. Google Scholar

Budiharto, T., Musat, E., Poortmans, P., Hurkmans, C., Monti, A., Bar-Deroma, R., Bernstein, Z., Van Tienhoven, G., Collette, L., \& Duclos, F. (2008). Profile 
Pengaruh Program Self Diabetes Management Education (SDME) dengan Metoda Kelompok terhadap Dukungan Keluarga dan Kualitas Hidup Pasien Diabetes Mellitus

Of European Radiotherapy Departments Contributing To The Eortc Radiation Oncology Group (Rog) In The 21st Century. Radiotherapy And Oncology, 88(3), 403-410. Google Scholar

Cheng, L., Feng, Y., Yang, J., \& Yang, J. (2009). Funnel Hopping: Searching The Cluster Potential Energy Surface Over The Funnels. The Journal Of Chemical Physics, 130(21), 214112. Google Scholar

Depkes, R. I. (2008). Farmakope Herbal Indonesia. In Jakarta: Departemen Kesehatan Republik Indonesia. Google Scholar

Dinkes, J. (2013). Profil Kesehatan Provinsi Jawa Tengah Tahun 2012. 2013. Semarang: Dinkes Jateng. Google Scholar

Erik, C. (2005). North Korea Under Communism: Report Of An Envoy To Paradise. Routledge. Google Scholar

Haas, L., Maryniuk, M., Beck, J., Cox, C. E., Duker, P., Edwards, L., Fisher, E., Hanson, L., Kent, D., \& Kolb, L.(2012). National Standards For Diabetes SelfManagement Education And Support. The Diabetes Educator, 38(5), 619-629. Google Scholar

Herdianti, H., Sari, N., Saputra, R., \& Hariansyah, F. D. (2020). Kalsium Hipoklorit (Caclo2) Sebagai Pengganti Larvasida Aedes Aegypti. Jurnal Kesehatan, 11(3), 422-428. Google Scholar

Ignatavicius, S. (2013). Stress In FemaleIdentified Transgender Youth: A Review Of The Literature On EffectsAnd Interventions. Journal Of Lgbt Youth, 10(4), 267-286. Google Scholar

Ligaray, K. P. L., \& Isley, W. L. (2009). Diabetes Mellitus, Type 2. Emedicine. United States, Medscape. Google Scholar
Nimas, M. (2012). Bioindustri Fermentasi Substrat Padat Dan Cair. Jurusan Teknologi Industri Pertanian. Universitas Brawijaya. Malang. Google Scholar

Notoatmodjo, S. (2010). Ilmu Perilaku Kesehatan. Penerbit Rineka Cipta. Google Scholar

Organization, W. H. (2002). Safety Of Medicines: A Guide To Detecting And Reporting Adverse Drug Reactions: Why Health Professionals Need To Take Action. World Health Organization. Google Scholar

Rapley, M. (2003). Quality Of Life Research: A Critical Introduction. Sage. Google Scholar

Sousa, D. Z., Smidt, H., Alves, M. M., \& Stams, A. J. M. (2009). Ecophysiology Of Syntrophic Communities That Degrade Saturated And Unsaturated Long-Chain Fatty Acids. Fems Microbiology Ecology, 68(3), 257-272. Google Scholar

Yuli, S., \& Harris, H. (2017). Tingkat Serangan Ektoparasit Pada Ikan Patin (Pangasius Hypopthalmus) Yang Dibudidayakan Dalam Keramba Jaring Apung Di Sungai Musi Palembang. Jurnal Ilmu-Ilmu Perikanan Dan Budidaya Perairan, 12(2). Google Scholar 


\section{Copyright holder:}

Ani Nuraeni (2021)

First publication right:

Jurnal Health Sains

This article is licensed under:

(c) (†) 